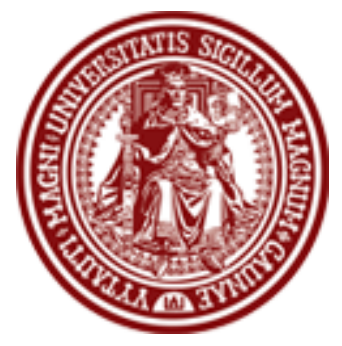

BALTIC JOURNAL OF LAW \& POLITICS

VOLUME 7, NUMBER 1 (2014)

ISSN 2029-0454

http://www.degruyter.com/view/j/bjlp

Cit.: Baltic Journal of Law \& Politics 7:1 (2014): 29-48

DOI: $10.2478 / \mathrm{bjlp}-2014-0003$

\title{
THE INVESTMENT ENVIRONMENT FOR RENEWABLE ENERGY DEVELOPMENT IN LITHUANIA: THE ELECTRICITY SECTOR
}

\section{Saulè Milčiuvienè}

Associate Professor, Head of Private Law Department, Ph.D. Vytautas Magnus University, Faculty of Law (Lithuania)

\section{Contact information}

Address: Ozeskienès str. 18, Kaunas 44254, Lithuania

Phone: +370 37751044

E-mail address: s.milciuviene@tf.vdu.It

\section{Julius Paškevičius}

\author{
Law Student \\ Vytautas Magnus University, Faculty of Law (Lithuania) \\ Contact information \\ Address: Ozeskienès str. 18, Kaunas 44254, Lithuania \\ Phone: +37037751044 \\ E-mail address: s.paskevicius@tf.vdu.It
}

Received: February 17, 2014; reviews: 2; accepted: May 7, 2014.

\begin{abstract}
The article analyzes the investment environment in renewable electricity generation capacities, evaluating the credibility of long term renewable energy targets, the stability of promotion schemes and the impartiality of national administrative procedure. The article explores two main questions: (i) are the EU and Lithuanian energy policy targets and promotion schemes credible enough to convince private investors to put their money in renewable energy development; (ii) does national administrative procedure put a disproportional burden on renewable energy investors or on certain group of investors? The assessment of the investment environment includes a large number of criteria, but we analyze three of them: the stability of long term strategy; the attractiveness of promotion
\end{abstract}


measures; and the simplicity and transparency of administrative procedure. Two further criteria are investigated: the stability of targets in renewable energy and the stability of promotional measures. The greatest uncertainty for investors occurs because of constantly changing support schemes of renewable energy sources-schemes that are not harmonized among the member States. At the national level the main driver in the development of small generators is the feed-in tariff. However, the high feed-in tariff does not always guarantee the smooth development of small scale generators of renewable energy.

\section{KEYWORDS}

Long term targets, promotion schemes, administrative procedure, renewable energy, national precedures 


\section{INTRODUCTION}

The support of renewable energy is a rather young direction for public policy. Denmark (1979), Portugal (1988), Germany (1989), and the United Kingdom (1989/90) were the first Member States in the EU, which began to support the development of renewable energy sources. Originally only the generation of electricity from renewable energy sources was supported; later the support schemes were applied to other energy sectors. Now it is broadly acknowledged that renewable energy sources in the future can solve problems of depleting fossil-based sources and could help fight climate change. ${ }^{1}$ For this reason the development of renewable energy sources is one of the top issues in national energy strategies in many states.

This article analyzes the investment environment in electricity generation from renewable energy sources capacities evaluating credibility of long term renewable energy targets, stability of promotion schemes and impartiality of national administrative procedure.

The article explores two main questions: (i) are the EU and Lithuanian energy policy targets and promotion schemes credible enough to convince private investors to put their money in renewable energy development; (ii) does national administrative procedure put a disproportional burden on renewable energy investors or on certain group of investors?

The assessment of the investment environment includes a large number of criteria, $^{2}$ but we analyze three of them: stability of long term strategy; the attractiveness of promotion measures; and the simplicity and transparency of administrative procedure. These criteria are chosen in order to analyze long term goals and to look how they resemble in administrative procedure.

As regulation of renewable energy falls within the shared competence of the EU and Member States the national long term strategy is analyzed together with the EU strategic renewable energy goals. The promotion measures of renewable energy are not regulated on the EU level; however, now it is evident that panEuropean renewable energy market cannot be created without some level of harmonization or renewable energy promotion measures among Member States. For this reason, national promotional measures will be analyzed together with those predominantly used in other Member States' promotional measures. The administrative procedure for getting licenses, installation, connection to the grid

\footnotetext{
1 José A. Fuinhas and António C. Marques, "Drivers promoting renewable energy: A dynamic panel approach," Renewable and sustainable energy reviews Vol. 15, No. 3 (2011).

2 Amel Bida, Hatem Elrefaei, Mohab Hallouda and Mohamed Elsobky, "Renewable energy market competence index part 1: The methodology," Renewable energy Vol. 53 (2013): 400-412.
} 
and operation of the renewable energy generators are purely national competence. The renewable energy directive only obliges Member States to avoid disproportional administrative measures. As promotional measures and administrative procedure are very different in every energy sector (electricity, heating, transport) the analysis is confined to electricity sector.

An increasing number of scientific articles in the field of renewable energy show a great interest of substantial awarness for this sector's perspectives. The main issues examined are promotion schemes and legal regulation problems, as well as assesment of how support schemes are implemented in Lithuania and what issues arise regarding attracting investments.

In Lithuania several scholars are doing research in energy law. However, significant research has been done by sociologists, economists and scholars of political science. The various issues concerning renewable energy are broadly analysed by scholars. D. Vasarevičius focuses on various promotional schemes of solar energy in Lithuania. ${ }^{3}$ A. Juškysdefines the main principals of renewable energy regulation EU law. ${ }^{4}$ D. Štreimikienè and I. Ališauskaitè-Šeškienèanalise write on the external costs of electricity generation. ${ }^{5}$ D. Štreimikienès and I. Konstantinavičiūtès analyze the application of the sustainable development indicators to the priorities of the development of energy sector. ${ }^{6}$ L. Mažylis and A. Pikšrytè analyze renewable energy obligations, which are binding to the Member States according the EU law, and issues which should be regulated by Member States. ${ }^{7}$ A. Pažeraitè and $M$. Karakauskas analyze the preconditions for smooth development of small business in the renewable sector taking into account political, economic, social and technical apects. ${ }^{8}$

Many scholars outside of Lithuania also analyze the various issues related to renewable energy: (i) the promotional schemes of renewable energy, ${ }^{9}$ the impact of the EU policy on renewable energy development, ${ }^{10}$ the impact of renewable energy

\footnotetext{
3 Darius Vasaravičius, "The analyses of the usages and perspectives of renewable energy sources in Lithuania," Science - Future of Lithuania Vol. 3, No. 1 (2011).

${ }_{4}$ Andrius Juškys, "Renewable energy regulation in European Union Law: development and trends," Current issues of Business and Law Vol. 7, No. 1 (2012).

5 Ilona Ališauskaitè-Šeškienè and Dalia Štreimikienè, "Evaluation of external costs of electricity generation technologies in Lithuania," Energy Vol. 59, No. 1 (2013).

${ }^{6}$ Inga Konstantinavičiūtè and Dalia Štreimikienè, "Lithuanian energy sector development priorities and sustainability indicators," Environmental Research, Engineering and Management Vol. 1, No. 23 (2003).

7 Liudas Mažylis and Aistè Pikšrytè, "EU regulatory policy models application in the renewable energy sector," Public policy and administration Vol. 12, No. 1 (2013).

8 Mindaugas Karakauskas and Aušra Pažerraitè, "Evaluation of the potential of small business development in the "Green Energy" sector," Energy Vol. 58, No. 4 (2012).

9 Reinhard Haas, Christian Panzer, Gustav Resch, Mario Ragwitz, Gemma Reece, and Anne Held, "A historical review of promotion strategies for electricity from renewable energy sources in EU countries," Renewable and sustainable energy reviews Vol. 15, No. 20 (2010).

${ }_{10}$ Pantelis Capros, Ger Klaassen, Leonidas Mantzos, Leonidas Parousos, Nikolaos Tasios, and Tom Van Ierland, "Analysis of the EU policy package on climate change and renewables," Energy policy Vol. 39, No. 3 (2011).
} 
to all energy sector, ${ }^{11}$ different models of climate change regulations ${ }^{12}$. In the most recent literature there was an attempt to deduce renewable energy competitiveness index based on eighteen criteria that could be adapted in any country. ${ }^{13}$

The regulation and technologies used to produce energy from renewable energy sources are changing constantly; therefore the social relations in this field are very dynamic and are raising new issues for investors. The relevance of the article rests in two dimensions of analysis: first, the EU and national strategy and regulation; second, renewable energy policy and administrative procedure. In this manner this article makes links among the EU energy policy, national energy policy and national administrative regulations.

\section{RENEWABLE ENERGY TARgETS AND PROMOTION SCHEMES: DO} INVESTORS FEEL SAFE?

This part of the article analyzes long term renewable energy policy. Two criteria are investigated - the stability of targets in renewable energy and stability of promotional measures. The question raised is: do EU and Lithuanian renewable energy targets and promotional measures are enough credible to convince investors to invest in renewable energy generation? The Lithuanian national energy strategy as well as development of renewable energy are analyzed together with the EU energy policy, because the major impact for Lithuanian renewable energy strategy has EU legal regulation.

\subsection{LONG TERM RENEWABLE ENERGY TARGETS}

Before the Lisbon treaty the environmental clause was the only suitable legal basis for renewable energy regulation in the EU. However, the Lisbon treaty introduced a new energy clause, which became the main legal basis for renewable energy regulations at the EU level. It states that "... Union policy on energy shall aim ... to ... promote ... development of new and renewable forms of energy. ${ }^{14}$ For this reason after the Lisbon treaty had come into force (2009) the EU acquired unquestionable competence to regulate renewable energy sectors at the EU level. ${ }^{15}$ The EU exercises its competence in renewable energy sector by adopting directives

\footnotetext{
11 José A. Fuinhas and António C. Marques, supra note 1.

12 Christoph Böhringer, Thomas F. Rutherford, and Richard S. J. Tol, "The EU 20/20/2020 targets: an overview of the EMF22 assessment," Energy economics Vol. 31, No. 2 (2009).

13 Amel Bida, Hatem Elrefaei, Mohab Hallouda, and Mohamed Elsobky, supra note 2.

14 Consolidated version of the Treaty on the Functioning of the European Union, Official Journal (2008, OJ C 115/50), Art. 194.

15 Saulè Milčiuvienè and Agnè Tikniūtè, "Legal regulation of renewable energy market," Jurisprudence Vol. 19, No. 4 (2012).
} 
and variable strategic documents (soft law). Consequently the trends of national regulation are based on the EU laws.

Two main EU documents for renewable energy sector should be mentioned: the European Commission Communication from the Commission Energy 2020 strategy for Competitive, Sustainable and Secure Energy ${ }^{16}$ and the Directive of 2009 on the Promotion of the Use of Energy from Renewable Sources ${ }^{17}$. These documents lay out the main goals of the current EU energy policy and the basic rules for promotion of renewable energy in the Member States.

Already in 2007 the European Commission proposed that by 2020 20\% of energy needs should be supplied from renewable energy sources (10\% renewable energy in transport, ${ }^{18} 33.9 \%$ electricity from renewable energy sources $)^{19}$. This renewable energy target is valid till now. If the EU-27 and individual Member States meet their renewable energy goals in 2020, 10 Member States will have more than $50 \%$ of their electricity produced from renewable energy sources, more than a half Member States will have 35\% or more electricity produced from renewable energy sources. The range of electricity produced from renewable energy sources varies from $5 \%$ in Estonia to $71 \%$ in Austria. ${ }^{20}$ The growing amount of renewable electricity proves the indispensable need to integrate renewable energy to pan European energy market. ${ }^{21}$

The Lithuanian national energy independence strategy, ${ }^{22}$ the renewable energy action plan 2010-2020, ${ }^{23}$ and the Republic of Lithuania Law on Energy from Renewable Sources ${ }^{24}$ are all implementing the EU legal regulations and all approve the target for renewable energy - 23\% in 2020 (transport sector - $10 \%$, electricity sector $-20 \%$, heating sector $-60 \%)^{25}$.

Recent analysis ${ }^{26}$ shows that the EU-27 and Lithuania reached their intermediate goal ${ }^{27}$ in development of renewable energy sources. The interim target

\footnotetext{
16 "Energy 2020 A strategy for competitive, sustainable and secure energy" (2010) // http://eurlex.europa.eu/LexUriServ/LexUriServ.do?uri=CELEX:52010DC0639:EN:HTML:NOT (accessed January 14, 2014).

17 Directive 2009/28/EC of the European Parliament and of the Council of 23 April 2009 on the promotion of the use of energy from renewable sources and amending and subsequently repealing Directives 2001/77/EC and 2003/30/EC, Official Journal (2009, OJ L 140/52).

18 Pantelis Capros, Ger Klaassen, Leonidas Mantzos, Leonidas Parousos, Nikolaos Tasios, and Tom Van Ierland, supra note 10.

19 Lena Kitzing, Catherine Mitchell, and Poul Erik Morthorst, "Renewable energy policies in Europe: Converging or diverging?" Energy Policy Vol. 51 (2012).

${ }^{20}$ Ibid.

${ }^{21}$ Ibid.

22 National Energy Independence Strategy, Official Gazette (2012, no. 80-4149).

23 "Renewable energy usage forecast for 2010-2020" (2009) //

http://www.enmin.It/It/activity/...energijos.../Prognoze.pdf (accessed January 14, 2014).

${ }^{24}$ Republic of Lithuania Law on Energy from Renewable Sources, Official Gazette (2011, no. 62-2936).

${ }^{25}$ National Energy Independence Strategy, supra note 22.

26 "Renewable energy progress report" (2013) //

http://eur-lex.europa.eu/LexUriServ/LexUriServ.do?uri=CELEX:52013DC0175:EN:NO (accessed January $14,2014)$.

${ }^{27}$ Calculated as the average of their 2011/2012 shares.
} 
of the EU is $10.7 \%$; however, in 2010 they had already reached $12.7 \%$. Lithuania's first interim target is $16.6 \%$, but in 2010 it had already reached $19.7 \%$. However the EU Commission in its green papers ${ }^{28}$ emphasized that although the current policy framework has resulted in strong growth of the renewable energy sector up to 2010, there should still be strong effort made to create certainty for investors, reduce the administrative burden and increase clarity in the planning.

One of the reasons to set targets for renewable energy development in national energy strategy is to send a signal for potential investors about the level of state commitment to support the investments in renewable energy. Therefore, the energy strategy should give signals for investors about priorities and policy trends of the government in development of renewable energy sources.

The attraction of investments in energy sector still remains a big challenge in the EU. ${ }^{29}$ According the dates of International Energy Agency in European electricity sector more than 1000 billion USD should be invested through 2030. Substantial investments are needed in electricity generation capacities. ${ }^{30}$ The annual investment volume in the EU-27 should be 60-70 billion euros in order to achieve $20 \%$ target in renewable energy production. ${ }^{31}$

Governments acknowledge the importance of investment in development of renewable energy sources. However even among politicians it is clear their preference is for short run benefits, because in the long run they will not be in the race for election any more. ${ }^{32}$ But particularly long term renewable energy policy is a key factor; it has a major impact on the decisions of new investments in electricity generation. Other criteria are volatility and unpredictability of future fossil fuels, carbon and electricity prices. These uncertainties also increase the financial risk of investment. $^{33}$

One study ${ }^{34}$ shows that the size of investments is critical to the development of renewable energy technologies; however the long run stability of the frame of governmental policy is even more influential. "Credibility requires officials to persuade others that government will follow through on actions promised.

${ }^{28}$ Green Paper, "A 2030 framework for climate and energy policies" (2013) // http://eurlex.europa.eu/LexUriServ/LexUriServ.do?uri=CELEX:52013DC0169:EN:NOT (accessed January $14,2014)$

${ }^{29}$ Lena Kitzing, Catherine Mitchell, and Poul Erik Morthorst, supra note 19.

30 Sandor Szabó and Arnulf Jäger-Waldau, "More competition: Threat or chance for financing renewable electricity?" Energy Policy Vol. 36, No. 4 (2008).

${ }^{31}$ Lena Kitzing, Catherine Mitchell, and Poul Erik Morthorst, supra note 19.

32 Richard Schmalensee, "Evaluating Policies to Increase Electricity Generation from Renewable Energy," Review Environmental Economy and Policy Vol. 6, No. 1 (2012).

${ }_{33}$ Sandor Szabó and Arnulf Jäger-Waldau, supra note 30.

34 Jiaqi Liang and Daniel J. Fiorino, "The Implications of Policy Stability for Renewable Energy Innovation in the United States, 1974-2009," Policy Studies Journal 41 (1) (2013). 
Credibility will especially important when the success of policy requires government to induce firms and individuals to make costly, irreversible investments. ${ }^{\prime 35}$

The stability of support for renewable energy proves the government's policy commitment and faith in the program. Credibility and rationale expectation are two of the most important issues in public policy, because rationale expectation of private investor reflects the information sent by policy makers. ${ }^{36}$

However, the question arises: are the EU and Lithuanian energy strategies credible enough to convince private investors to put their money in renewable energy development?

Concerning targets in renewable energy development the EU and Lithuania seem to be consistent, with the exception of the recent proposal of the EU Commission to modify the target in biofuels. Already in the first independent Lithuanian energy strategy (1994) the government expressed its commitment ${ }^{37}$ to support the development of renewable energy sources. In the National energy strategy of 2002 Lithuania set a target of $12 \%$ renewable energy in $2010 .{ }^{38}$ In 2001 the EU adopted the directive on the promotion of electricity produced from renewable energy sources. ${ }^{39}$ This directive set a target of $12 \%$ of gross national energy consumption by 2010 and in particular with the 22,1\% indicative share of electricity produced from renewable energy sources in total Community electricity consumption by 2010. Also in 2003 the EU adapted the directive on the promotion of the use of biofuels or other renewable fuels for transport. ${ }^{40}$ It set a $5,75 \%$ target of all petrol and diesel for transport purposes placed on their markets by the end of 2010.

The possible instability of promotion of renewable energy is revealed in the recent discussions in the EU institution about the new targets of biofuels. There is a 2009 directive which approved targets of the usage of biofuels (10\% by 2020 in transport sector). The Commission submitted a proposal ${ }^{41}$ amending Directive 98/70/EC relating to the quality of petrol and diesel fuels and amending Directive $2009 / 28 / E C$ on the promotion of the use of energy from renewable sources. In the

\footnotetext{
35 Ibid.

36 Ibid.

37 The National Energy Complex Development Plan, Official Gazette (1994, no. 30-545).

38 National Energy Independence Strategy, supra note 22.

39 Directive 2001/77/EC of the European Parliament and of the Council of 27 September 2001 on the promotion of electricity produced from renewable energy sources in the internal electricity market, Official Journal (2001, OJ L 283), Art. 33-40.

${ }^{40}$ Directive 2003/30/EC of the European Parliament and of the Council of 8 May 2003 on the promotion of the use of biofuels or other renewable fuels for transport, Official Journal (2003, 0J L 123), Art. 4246.

41 "Proposal for a Directive of the European Parliament and of the Council amending Directive 98/70/EC relating to the quality of petrol and diesel fuels and amending Directive 2009/28/EC on the promotion of the use of energy from renewable sources" (2012) // http://ec.europa.eu/clima/policies/transport/fuel/docs/com_2012_595_en.pdf (accessed January 14, 2014).
} 
proposal of the Commission the use of food-based biofuels is limited to $5 \%$ (compared to $10 \%$ renewable energy target of the renewable energy directive (2009)). The aim of this limitation is to promote the usage of second generation biofuels from non-food feedstock (e.g. waste or straw) and to avoid interference in global food production. It means that biofuel, which is made from crops grown on land that can be used to be rainforest or natural grassland, is no longer considered sustainable.

Lithuania already before the proposal of the EU Commission has once reduced its biofuels targets. In the Forecast document of renewable energy use 2010$2020,{ }^{42}$ the Lithuanian target for biofuels in transportation sector is $15 \%$; however in National Energy Strategy (2012) this target is reduced to $10 \%$. If the EU institutions adopt the above mentioned changes to biofuels target, it is likely that Lithuania will follow in reducing its biofuels targets.

We can conclude that the commitment of Lithuania and the EU to promote renewable energy development is steady and credible. However for private investors it is not enough to know that the government will promote renewable energy-the steadiness of long run support schemes is also very important. The effectiveness of support instruments depends on the credibility of the system for potential investors. The government must guarantee that promotional strategy will be valid till a specified date. Otherwise the investors will not be willing to invest, because the risk is too high. ${ }^{43}$

Therefore, it is clear that Lithuania and the EU are steadily promoting the development of renewable energy sources; however the question remains what support instrument it will use and to what extent the renewable will be supported.

\subsection{PROMOTION MEASURES FOR RENEWABLE ENERGY}

In most cases the methods of price and quantity control are used to promote renewable energy in Member States. ${ }^{44}$ The commonly used price control methods are: feed-in tariff, feed-in premium, tender ${ }^{45}$ and quantity control method tradable green certificate. Other types of incentives related to the electricity price,

\footnotetext{
42 "Renewable energy usage forecast for 2010-2020," supra note 23.

43 Reinhard Haas, Christian Panzer, Gustav Resch, Mario Ragwitz, Gemma Reece, and Anne Held, supra note 9.

44 Julián Barquín, Riccardo Fagiani, and Rudi Hakvoort, "Risk-based assessment of the cost-efficiency and the affectivity of renewable energy support schemes: Certificate markets versus feed-in tariffs," Energy policy Vol. 55 (2013).

45 "Financing renewable energy in the European energy market" (2011) //

http://ec.europa.eu/energy/renewables/studies/doc/renewables/2011_financing_renewable.pdf (accessed January 14, 2014).
} 
fiscal incentives, and subsidies ${ }^{46}$ are not so common in Member States, and therefore they will not be examined.

A feed-in tariff has two advantages: it creates certainty for investors and reduces the costs of the project. ${ }^{47}$ As global practice shows, a feed-in tariff is very attractive for investors in electricity generation, ${ }^{48}$ because they can easly predict future cash flows. ${ }^{49}$ Also the banks tend to provide lower credit rates in the Member States as applied to the feed-in tariff. ${ }^{50}$

For example, in Germany a premium feed-in scheme is used in conjuction with feed-in tariff which permits the sale of produced electricity in electricity exchange or by contract. The margin of electricity price, the area of which is compensated by renewable energy producers, is the difference of the feed-in tariff and market price plus expenses which occur in the process of trading. ${ }^{51}$

In EU Member States a quota or tradable green certificate promotion measures are also applied. According to these promotion measures every year the government determines the amount of electricity which is going to be produced from renewable resources, and awards renewable energy producers with certificates depending on their generation capacities. Producers' incomes are divided into two parts: one part is received from selling produced electricity in the market and the second part comes from selling certificaties in a special designed market where other electricity market participants are obliged to buy a certain amount of certificates.

From the investor's point of view quota or tradable green certificate schemes have a lot of uncertainty. They are based on principals of free trade. The prices of a certificate can drop extremely low because of high supply volumes. Also investors become very sceptical about investments in capacities of renewable electricity because of the volatility of elecricity price. ${ }^{52}$ Trying to sell certificaties in the market, the investors have additional financial expenditure ${ }^{53}$ and it requires special knowledge, which not every potential investor has ${ }^{54}$. Also quota or tradable green certificate promotion measures stimulate investmenst in cheaper technologies and accordingly prevent investments in the expensive but more advanced technologies. For example, wind generators are cheaper then solar ones and attract much more

46 Ibid.

47 Lincoln L. Davies, "Reconciling renewable portfolio standard and feed-in tariffs," Utah Environmental Law Review Vol. 32, No. 2 (2013).

${ }^{48}$ Felix Mormann, "Enhancing the investors appeal of renewable energy," Environmental Law Vol. 42 (2012).

49 Lincoln L. Davies, supra note 47.

50 "Financing renewable energy in the European energy market," supra note 45.

${ }^{51}$ Ingrid Bozsoki, "Electricity promotional in Germany. RES LEGAL European Commission" (2013) // http://www.res-legal.eu/search-by-country/germany/summary/c/germany/s/res-e/sum/136/lpid/135/

(accessed January 14, 2014).

52 Felix Mormann, supra note 48

53 Ibid.

${ }^{54}$ Ibid. 
investment compared to expensive solar technologies. For this reason usually Tradable Green Certificate measures are aplied together with feed-in tariff or premium feed-in schemes. ${ }^{55}$

Member States use different renewable energy promotion measures, because the renewable energy directive ${ }^{56}$ does not harmonize with the support schemes of renewable energy among Member States. They can choose the most appropriate support scheme for their local conditions. However the different support schemes create a different legal and financial environment for investors in different Member States, which prevents the formation of pan European renewable energy market.

The renewable energy directive ${ }^{57}$ suggests only three cooperation options among Member States: (i) statistical transfers, i.e. the data of renewable production transferred from statistics of one Member State's to another's; (ii) joint projects, i.e. Member States jointly set framework conditions for projects, this may include that one Member State provides support payments to a project in another Member State; (iii) joint support scheme, i.e. Member States define a joint support and then use statistical transfers to allocate renewable production among themselves. ${ }^{58}$

These cooperation schemes do not have a major effect on the development of a pan European renewable energy market. If nothing is changed, it is expected that cross border trade will account for only $0.4 \%$ of the EU renewable production in $2020 .^{59}$ However $6 \%$ trade of renewable energy or renewable obligations among the Member States could lead to reduction of additional costs for renewable of more than $25 \% .^{60}$

In order to stimulate the formation of a pan European renewable energy market the European Commission seeks the convergence of national support schemes. It states that "the greater convergence of national support schemes to facilitate trade and move towards a more pan European approach to development of renewable energy sources must be pursued." ${ }^{161}$ In 2007 Token stated: "Problems begin to creep in when people start making proposals for the same incentives to be given anywhere in Europe ... . A harmonized EU-wide market based system, would not improve cost effectiveness, and may serve to reduce, rather to increase, local

\footnotetext{
55 "Financing renewable energy in the European energy market," supra note 45.

56 Directive 2009/28/EC, supra note 17.

57 Ibid.

58 Lena Kitzing, Catherine Mitchell and Poul Erik Morthorst, supra note 19.

59 Pantelis Capros, Ger Klaassen, Leonidas Mantzos, Leonidas Parousos, Nikolaos Tasios, and Tom Van Ierland, supra note 10.

60 Ibid.

${ }^{61}$ Lena Kitzing, Catherine Mitchell and Poul Erik Morthorst, supra note 19.
} 
investments in renewable energy. ${ }^{\prime 62}$ However, today the harmonization of support schemes of Member's Sates is more likely.

The convergence of national support schemes increases the possibility for regional cooperation among member states. However now Member States have established national support schemes and investors have legitimate expectations for the established promotion measures. For this reason Member States will hardly be able to give up traditional support measures because of promises made to investors. ${ }^{63}$

Already preparing the project of directive 2009/28/EC two different approaches for the harmonization of renewable energy support schemes were proposed: (i) the "top down" approach; and (ii) the "bottom-up" approach. The "top down" approach suggests that support schemes should be fully harmonized on the EU level among Member States. The "bottom-up" approach suggests that all Member States can independently choose the support schemes and policies, expecting that benefit of renewable energy common market and emergence of the most effective support schemes will lead to a unified support scheme. The "bottomup" approach is implemented in a directive. The discussion on regional harmonization of support schemes began later, for example between Sweden and Norway. ${ }^{64}$

The "bottom-up" convergence is possible, if the Member States express willingness to identify the best practice of support of renewable energy sources and implement it at national level. It is possible to reveal two major trends: (i) the dominant use of price control instruments (especially feed in tariff for small installations); and, (ii) the use of multiple support instruments at the same time. Denmark applies six policy types for support of renewable energy, while France, Portugal, Italy, Netherlands and Spain apply four to five. ${ }^{65}$

Although the price controlled instruments are dominant and the "bottom-up" convergence is happening, there are also Member States which do not apply price controlled mechanisms at all. So the dominant trends do not include all countries ${ }^{66}$ and it is the biggest obstacle for the creation of a pan European renewable energy market, and for this reason "top-down" harmonization is unavoidable.

Financial engineering is a new way of renewable support and is promoted by the European Commission. The Guidance Note on financial Engineering

62 David Toke, "Renewable financial support systems and cost-effectiveness," Journal of Cleaner Production Vol. 15, No. 3 (2007).

${ }^{63}$ Lena Kitzing, Catherine Mitchell and Poul Erik Morthorst, supra note 19.

${ }^{64}$ Ibid.

${ }^{65}$ Ibid.

${ }^{66}$ Ibid. 
Instruments ${ }^{67}$ strongly supports the Member States in applying financial engineering instruments. This means that the support schemes of renewable energy can move in this direction.

From this analysis it can be concluded that the renewable energy sector is regulated on the EU level, so the national targets very much depend on the decisions made in the EU institutions. Lithuania and the EU promotes the development of renewable energy steadily; however the set targets can be changed in the case of necessity. The biggest uncertainty for investors occurs because of constantly changing support schemes of renewable energy sources-schemes that are not harmonized or coordinated among Member States. Whether the support schemes will be harmonized at the EU level remains the key question.

\section{ADMINISTRAVIVE PROCEDURE: THE CASE OF LITHUANIA}

In Lithuania as in all other Memeber States the development of renewable energy sources is promoted by the government, because renewable energy is still uncompetetive compared to conventional energy sources.

In Lithuania legal acts set two different procedures for the instalation of renewable energy generation capacities in the electricity sector: one for "small power generators", which have generation capacities not bigger than $10 \mathrm{~kW}$, and another one for "big power generators" with generation capacity above $10 \mathrm{~kW} .{ }^{68}$ This division is important because legal acts set different requirements of licensing, connection to the grid regulation and electricity trade procedures for small and big power generators.

\subsection{ADMINISTRAVIVE PROCEDURE FOR SMALL SCALE GENERATION} CAPACITIES

Promotion measures for small power generators are simpler than for big power generators. The primary goal of smallpower generators is to provide electricity to households but not to the market.The small power generators can sell only $50 \%$ of all produced electricity per year to the grid operator at a set price. ${ }^{69}$

The developers of small power generators for households do not need to get licenses for construction of generators and generation of electricity. ${ }^{70}$ The main

\footnotetext{
67 "Guidance Note on Financial Engineering Instruments under Article 44 of Council Regulation (EC) No 1083/2006" (2011) //

http://ec.europa.eu/regional_policy/archive/funds/2007/jjj/doc/pdf/cocof_guidance_note3_en.pdf (accessed January 14, 2014).

${ }^{68}$ Republic of Lithuania law on energy from renewable sources, Official Gazette (2011, no. 62-2936).

${ }^{69}$ Ibid.

${ }^{70}$ Ibid.
} 
obligation is to inform the grid operator about the amount of electricity which will be produced and supplied to the grid. The grid operator is obliged to buy up to $50 \%$ of the produced electricity per year at set feed-in tariff. The households can get benefits from feed-in tariff for 12 years. ${ }^{71}$

It can be concluded that the main driver for the development of small generators is the feed-in tariff. However a high feed-in tariff does not always guarantee the smooth development of small scale generators of renewable energy. The high installation costs and a constantly changing feed-in tariff can impede the development of small scale renewable energy generation, because investors in renewable energy for the household needs are usually small investors, who are not willing to take the risk.

\subsection{ADMINISTRAVIVE PROCEDURE FOR LARGE SCALE GENERATION} CAPACITIES

The large scale power plants (above $10 \mathrm{~kW}$ ) are regulated more rigorously since they are designed for commercial activity. Process from document submission until electricity trade can be divided into separate stages: first stage - signing letter of intention with grid operator; second stage - participating in feed-in tariff auction; third stage - connecting to the grid; fourth - supllying electricity to the grid; fifth stage - electricity trading. We will analyze all of the procedures according to this separation.

During the first stage the investor evaluates the reasonableness of investments. Primarily the grid operator issues the non-binding preliminary terms of the connection to the grid. According to these terms the investor evaluates the necessary amount of investments. The preliminary terms are valid no more than six months; thus, if the investor does not make a decision during this period, he has to apply for preliminary terms to the grid operator again. If the investor decides to invest, the grid operator and investor sign a binding letter of intent to connect certain capacities to the grid, which is binding for both parties. The investor is required to place warranty of obligation fulfillment. ${ }^{72}$

Second stage is the participation in free capacities reverse auction. Separate auctions are organized for every type of renewable energy source. The participants are obliged to present the warranty of the fulfillment of obligation to produce electricity. The National Control Commission for Prices and Energy organizes a reverse auction, which means that the participant who offers the lowest electricity production price and largest production capacities wins. When the same price and

\footnotetext{
${ }^{71}$ Promotional Rules for Renewable Energy Resources, Official Gazette (2012, no. 827).
}

72 Republic of Lithuania Law on Financial Institutions, Official Gazette (2002, no. 91-3891). 
production capacities are offered by several participants and the sum of proposed capacities exceed available capacities, the available capacities are divided among these participants proportionally. If available capacities remain unused, it can be divided for other participants. However, these participants should agree to produce electricity at the same price as the winner of the auction. All winners get a feed-in tariff for twelve years from issuing production license.

It is clear that regulation is more favorable to big investors. If the small investor and large investor offer the same electricity production price, the large investor will win because it has ability to offer large production capacities.

The third stage is the physical connection of the renewable energy power plant to the grid. The investor who connects to the grid the renewable energy power plants with capacity of $350 \mathrm{~kW}$ and less gets $20 \%$ compensation of actual connection costs. The investor who connects to the grid the renewable energy power plants with capacity above $350 \mathrm{~kW}$ gets $40 \%$ compensation of their actual connection costs. ${ }^{73}$ The main issue in this stage is that the grid operator is allowed to issue differnt terms of the conection to the grid than what was specified in preliminary terms. For this reason the investments necesary to connect power plant to the grid can sharply increase. ${ }^{74}$ However, even if in this stage the investor understands that because of sharply increased investvent the production of electricity at set price will not be profitable, he is forced to invest. Otherwise he will lose warranty of obligation to produce elelctricity. In this manner the principles of legal certainty and legitimate expectation are disregarded. Investments become risky because of the above-mentioned uncertainties.

The fourth stage is supllying electricity to the grid.The producers of electricity from renewable energy sources have priority over other electricity producers to supply electricity to the grid. Also they do not have to pay for balancing services. Because of priority to supplying electricity to the grid the renewable energy power plants can use all their capacity in certain weather conditions. Avoiding to overload the grid exceptions are made for wind generators, which are above $350 \mathrm{~kW}$, and hidro generators - above $5 \mathrm{MW}$. These large capacities for renewable energy production can be disconnected from the grid in case of necessity. ${ }^{75}$

The fifth stage is electricity trading. The producer has the right during the promotional period to change the price setting model from feed-in tariff to premium feed-in. According to the premium feed-in model the investor may sell electricity in electricity exchange or through bilateral agreements.The main disadvantage of the premium feed-in model is that additional costs which occur in the proccess of

\footnotetext{
73 Republic of Lithuania Law on Energy from Renewable Sources, supra note 24.

${ }^{74}$ Grid operating rules for electricity producers, Official Gazette (2012, no. 03-159).

${ }^{75}$ Republic of Lithuania Law on Energy from Renewable Sources, supra note 24.
} 
trading electricity in exchange or through agreements, is not compensated to the electricity producers.For this reason when electricity is sold directly to the grid operators at fixed price, the feed-in tariff is more attractive.

On the basis of this analysis, we may conclude that the legal regulation of large scale renewable energy power generators is more favourable to large inverstors rather than small investors. Large investors have the finacial capacity to invest in huge generation capacities and assume certain financial risk. This conclusion is based on the findings that: (i) the participant who offers not only the lowest electricity production price but also the largest production capacities wins; (ii) in many stages the warranties of obligation fulfillment is required and this can be an unreasonable financial burden to small investor; (iii) uncertain conditions of generation capacities connection to the grid place unreasonable risk on small investors; (iv) an investor connecting to the grid the renewable energy power plants with capacity above $350 \mathrm{~kW}$ gets $40 \%$ compensation of their actual connection costs, and others with less capacity get only $20 \%$ compensation.

\section{CONCLUSIONS}

1. The investment to renewable energy technologies is long term and supported by the state, therefore investors are very sensitive to the changes of public policy. The stability of renewable energy targets and promotional measures are key factors for attracting investment in renewable energy sector.

1.1. After Lisbon treaty the EU acquired unquestionable competence to regulate renewable energy sector, for this reason national renewable energy strategies are very dependent on the EU regulation. According the EU legislation Member States announced national renewable energy targets, which are rather stable, except target for biofuels.

1.2. The EU legal regulation does not set the common renewable energy promotion scheme, every Member State is free to choose public policy instruments in order to reach renewable energy targets. The lack of common framework of renewable energy promotion measures results in constant changes of promotion measures in different Member States and precludes the creation of Pan-European renewable energy market.

2. In Lithuania legal acts apply two different procedures for the installation of renewable energy generation capacities in the electricity sector: one for "small power generators", which has generation capacities not greater than $10 \mathrm{~kW}$, and another one for "big power generators" with generation capacity above $10 \mathrm{~kW}$. 
2.1. The primary puprpose of "small power generators" are usually to generate energy for inner consumption and onlly suprlpus of energy is supplied to the grid. Normally they are small investors, who do not want to take a risk but to have stable and secured benifit, therefore stable legal enviroment than possible but uncertain profit is more important for them.

2.2 "Big power generators" are usually bussines enterprices, which can make more risky investmenst hoping for bigger profit in future. The made analysis showed that companies, which has finacial capacity to assume risk is in better possition to invevest is renwable energy sector than small bussines enterprices.

\section{BIBLIOGRAPHY}

1. Ališauskaitè-Šeškienè, Ilona, and Dalia Štreimikienè. "Evaluation of external costs of electricity generation technologies in Lithuania." Energy Vol. 59, No. 1 (2013): 11-19.

2. Barquin, Julian, Riccardo Fagiani, and Rudi Hakvoort. "Risk-based assessment of the cost-efficiency and the affectivity of renewable energy support schemes: Certificate markets versus feed-in tariffs." Energy policy Vol. 55 (2013): 648-661.

3. Bida, Amel, Hatem Elrefaei, Mohab Hallouda, and Mohamed Elsobky. "Renewable energy market competence index part 1: The methodology." Renewable energy Vol. 53 (2013): 400-412.

4. Böhringer, Christoph, Thomas F. Rutherford, and Richard S. J. Tol. "The EU 20/20/2020 targets: an overview of the EMF22 assessment." Energy economics Vol. 31, No. 2 (2009): 268-293.

5. Bozsoki, Ingrid. "Electricity promotional in Germany. RES LEGAL European Commission." (2013) //http://www.res-legal.eu/search-bycountry/germany/summary/c/germany/s/res-e/sum/136/lpid/135 (accessed January 14, 2014).

6. Capros, Pantelis, Ger Klaassen, Leonidas Mantzos, Leonidas Parousos, Nikolaos Tasios, and Tom Van Ierland. "Analysis of the EU policy package on climate change and renewables." Energy policy Vol. 39, No. 3 (2011): 14761485.

7. Consolidated Version of the Treaty on the Functioning of the European Union. Official Journal, 2008, C 115/50.

8. Davies, Lincoln L. "Reconciling renewable portfolio standard and feed-in tariffs." Utah Environmental Law Review Vol. 32, No. 2 (2013): 311-361. 
9. Directive 2001/77/EC of the European Parliament and of the Council of 27 September 2001 on the promotion of electricity produced from renewable energy sources in the internal electricity market. Official Journal, 2001, L 283.

10. Directive 2003/30/EC of the European Parliament and of the Council of 8 May 2003 on the promotion of the use of biofuels or other renewable fuels for transport. Official Journal, 2003, L 123.

11. Directive 2009/28/EC of the European Parliament and of the Council of 23 April 2009 on the promotion of the use of energy from renewable sources and amending and subsequently repealing Directives 2001/77/EC and 2003/30/EC. Official Journal, 2009, L 140/52.

12. "Energy 2020 A strategy for competitive, sustainable and secure energy" (2010) // http://eur-

lex.europa.eu/LexUriServ/LexUriServ.do?uri=CELEX:52010DC0639:EN:HTML: NOT (accessed January 14, 2014)

13. "Financing renewable energy in the European energy market" (2011) // http://ec.europa.eu/energy/renewables/studies/doc/renewables/2011_financi ng_renewable.pdf (accessed January 14, 2014).

14. Fuinhas, José A., and António C. Marques. "Drivers promoting renewable energy: A dynamic panel approach." Renewable and sustainable energy reviews Vol. 15, No. 3 (2011): 1601-1608.

15. Green Paper. "A 2030 framework for climate and energy policies" (2013) // http://eurlex.europa.eu/LexUriServ/LexUriServ.do?uri=CELEX:52013DC0169: EN:NOT (accessed January 14, 2014).

16. Grid Operating Rules for Electricity Producers. Official Gazette,2012, no. O3159.

17. "Guidance Note on Financial Engineering Instruments under Article 44 of Council Regulation (EC) No 1083/2006" (2011) // http://ec.europa.eu/regional_policy/archive/funds/2007/jjj/doc/pdf/cocof_gui dance_note3_en.pdf (accessed January 14, 2014).

18. Haas, Reinhard, Christian Panzer, Gustav Resch, Mario Ragwitz, Gemma Reece, and Anne Held. "A historical review of promotion strategies for electricity from renewable energy sources in EU countries." Renewable and sustainable energy reviews Vol. 15, No. 20 (2010): 1003-1034.

19. Juškys, Andrius. "Renewable energy regulation in European Union Law: development and trends." Current issues of Business and Law Vol. 7, No. 1 (2012): 183-200. 
20. Karakauskas, Mindaugas, and Aušra Pažèraitè. "Evaluation of the potential of small business development in the "Green Energy" sector." Energy Vol. 58, No. 4 (2012): 186-194.

21. Kitzing, Lena, Catherine Mitchell, and Poul Erik Morthorst. "Renewable energy policies in Europe: Converging or diverging?" Energy Policy Vol. 51 (2012): 192-201.

22. Konstantinavičiūtè, Inga, and Dalia Štreimikienè. "Lithuanian energy sector development priorities and sustainability indicators." Environmental Research, Engineering and Management Vol. 1, No. 23 (2003).

23. Liang, Jiaq, and Daniel J. Fiorino. "The Implications of Policy Stability for Renewable Energy Innovation in the United States, 1974-2009." Policy Studies Journal 41 (1) (2013): 97-118.

24. Mažylis, Liudas, and Aistè Pikšrytè. "EU regulatory policy models` application in the renewable energy sector." Public policy and administration Vol. 12, No. 1 (2013): 120-132.

25. Milčiuvienè, Saulè, and Agnè Tikniūtè. "Legal regulation of renewable energy market." Jurisprudence Vol. 19, No. 4 (2012): 1495-1513.

26. Mormann, Felix. "Enhancing the investors appeal of renewable energy." Environmental Law Vol. 42 (2012): 681-734.

27. National Energy Independence Strategy. Official Gazette, 2012, no. 80-4149.

28. Promotional Rules for Renewable Energy Resources. Official Gazette, 2012, no. 827.

29. "Proposal for a Directive of the European Parliament and of the Council amending Directive 98/70/EC relating to the quality of petrol and diesel fuels and amending Directive 2009/28/EC on the promotion of the use of energy from renewable sources" (2012) //

http://ec.europa.eu/clima/policies/transport/fuel/docs/com_2012_595_en.pdf (accessed January 14, 2014).

30. "Renewable energy progress report" (2013) // http://eurlex.europa.eu/LexUriServ/LexUriServ.do?uri=CELEX:52013DC0175:EN: NO (accessed January 14, 2014).

31. "Renewable energy usage forecast for 2010-2020" (2009) // http://www.enmin.It/It/activity/...energijos.../Prognoze.pdf (accessed January $14,2014)$.

32. Republic of Lithuania Law on Energy From Renewable Sources. Official Gazette, 2011, no. 62-2936.

33. Republic of Lithuania Law on Financial Institutions. Official Gazette, 2002, no. 91-3891. 
34. Schmalensee, Richard. "Evaluating Policies to Increase Electricity Generation from Renewable Energy." Review Environmental Economy and Policy Vol. 6, No. 1 (2012): 45-64.

35. Szabó, Sandor, and Arnulf Jäger-Waldau. "More competition: Threat or chance for financing renewable electricity?" Energy Policy Vol. 36, No. 4 (2008): 1436-1447.

36. The National Energy Complex Development Plan. Official Gazette, 1994, no. 30-545.

37. Toke, David. "Renewable financial support systems and cost-effectiveness." Journal of Cleaner Production Vol. 15, No. 3 (2007): 280-287.

38. Vasaravičius, Darius. "The analyses of the usages and perspectives of renewable energy sources in Lithuania." Science - Future of Lithuania Vol. 3, No. 1 (2011): 73-77. 